\title{
The role of NGOs in corporate environmental responsibility practice: evidence from Ethiopia
}

\author{
Tibebe Sirak Asfaw*, Vida Botes and Lula G. Mengesha
}

\begin{abstract}
This research explores the role of Non-Government Organizations (NGOs) in corporate environmental responsibility practice within the context of a developing country, Ethiopia, and provides a framework that enables NGOs to influence firms to improve environmental performance and increase environmental disclosure. This research is a qualitative research which employs content analysis. The result of the study shows that the environmental NGOs in Ethiopia are engaged more on reacting to the damage that has been caused by the unsustainable business practices rather than working proactively by collaborating with corporations, government and other stakeholders. This implies that donors should play a pivotal role in this regard since it is the donors' thematic area of activities that dictates the NGOs projects and programs.
\end{abstract}

Keywords: NGOs, Corporate Environmental Responsibility, Stakeholder, Ethiopia

\section{Introduction}

According to the seminal works by Clarkson (1995), Donaldson and Preston (1995) and Mitchell, et al., (1997), companies should be more responsive for primary stakeholders in terms of better environmental performance as a result of their direct financial relationship with them. Furthermore, their seminal works argue that companies should be less responsive to secondary stakeholders mainly because they lack direct financial interaction. A good deal of research have also indicated that government has been criticized for not influencing companies to improve their environmental performance.

There are a number of arguments that can be drawn here with regard to the validity of the above seminal work. First, it should be noted that their seminal works are more relevant to developed countries than developing countries. This is because the issue of environmental awareness by consumers is somehow well known in the developed countries than developing countries. It is also more unlikely for employees in the developing countries to refuse to work for companies having poor environmental performance as there is high unemployment rate and less job security.

\footnotetext{
*Correspondence: tibebes@hotmail.com

The University of Waikato, Hamilton, New Zealand
}

Second, in the context of developing countries, NonGovernmental Organisations (NGOs) are well positioned to have powerful impact on corporate environmental performance than any other stakeholder. This argument is based on the fact that NGOs are generally regarded as important stakeholders, representatives of key stakeholder groups and most trusted institution as pointed out by Arenas et al. (2009), Danastas \& Gadenne (2006) and Burgos (2012) respectively. Moreover, NGOs are regarded as vindicators of the general society, stakeholders' catalyst and proxy for non-human nature as indicated by Tilt (1994), Rodgers (2000) and Starik (1995) respectively. Third, even if NGOs do not have direct financial relationship with the companies, they can bring an adverse effect on the financial performance of the companies by using confrontational strategies. As a result, they can play influential role in corporate environmental responsibilities practice by mobilizing primary stakeholders to sign petitions, boycott and protest against companies which are recognised as poor environmental performer.

This research considers the above arguments and attempts to examine the role of NGOs in corporate environmental responsibility practice by taking the case of Ethiopian. According to the 2014 Environmental 
performance index published by Yale University, Ethiopia ranked 131st of 178 countries (Yale University, 2014). A recent study by the Ministry of Environment and Forestry reveals that out of the 163 factories surveyed 101 (61.93\%) release their industrial wastes directly to the environment without any treatments (Ministry of Environment and Forestry, 2014). By taking these major environmental issues of Ethiopia into consideration, our study contributes to the existing studies in three key areas. First, it brings a perspective from a developing country, Ethiopia, into the studies of corporate environmental responsibilities. Second, it provides a contribution to the literature on secondary stakeholders. Third, it provides an original framework that environmental NGOs can make use of in influencing companies to improve their environmental performance.

This paper is organised as follows: the next section discusses the literature review, section 3 presents data collection and methodology, section 4 discusses the findings and section 5 presents the conclusion.

\section{Literature review}

Scholars have studied the motivational factors, the sufficiency, the reliability and other aspects of corporate environmental responsibility and/or disclosures in developing countries (see De Villiers and van Staden, 2006; Ackers, 2009; De Villiers, 2003; Pratten and Mashat, 2009; Kabir and Akinnusi, 2012; Ofori and Hinson, 2007; Elijido-Ten et al., 2010; Islam and Deegan, 2008; and Belal and Owen, 2007). In contrast to these studies, very limited scholars have specifically studied with regard to the NGOs and the corporate environmental responsibility in the context of developed and developing countries (Tilling, \& Davidson, 2006).

The study by Deegan and Blomquist (2006) conclude that lobby groups are presumed to be a major source of pressure in terms of corporate social disclosure in the case of Australia. Likewise, Yaziji and Doh (2009) report how Coca-Cola was the target of a snowballing global campaign by NGOs that cost the company millions of dollars in India. O'Dwyer et al. (2005) also investigate on NGOs' perception of environmental disclosure in Ireland and find out that the NGOs require stand-alone, mandated, externally verified corporate social and environmental disclosure mechanisms. The study by Tilt (2004) on the influence of NGOs on corporate social disclosure in Australia indicates that the relationship between NGOs and companies has changed over time without any change on the attitude and actions of NGOs. Similarly, Tilling \& Davidson (2006) investigates how NGOs in Australia engage in activism through highlighting corporate activities using their webpages.

From developing countries context, Belal \& Roberts (2010) study the perception of non-managerial stakeholders including NGOs in Bangladesh and find an overwhelming support for the need by the NGOs for mandatory environmental responsibility report from companies. In the same way, Momin (2013) examines social and environmental NGOs' perceptions of corporate social disclosures and conclude that NGOs need to require companies in Bangladesh to take strong action than words.

NGOs play great role in environmental sustainability by addressing climate change, energy, waste management, pollution, biodiversity and land use. The study by Sandhu and Arora (2012) shows that some environmental NGOs play significant role in collaboration with the government, corporations and villagers on carbon emissions, in protecting forest and revenue wasteland, in creating awareness on water and air pollution as well as in bringing important environmental issues to the forefront.

The relationship between NGOs and companies has been manifested through the strategies and tactics that the NGOs use to impact the practice of the companies. There are a wide array of strategies and tactics available to NGOs to influence companies practice (Winston, 2002), and these strategies and tactics can be categorized either as collaborative or confrontational (Arenas et al., 2009; Bakker, 2012; Deegan \& Blomquist, 2006; Fiedler \& Deegan, 2007).

Gray (1989, p.5) defines collaboration as 'a process through which parties who see different aspects of a problem can constructively explore their differences and search for solutions that go beyond their own limited vision of what is possible. Collaboration is central to partnerships (Hartman et al. 1999). According to Ählström and Sjöström (2005, P. 8), 'No collaboration' means "no partnerships, no joint action, no sponsorship financing and in most cases no donations." Environmental NGOs-Corporation collaborations exists when "two or more parties working together in relation to natural environmental issues, where at least one of the parties is an organisation from industry, and another, a non-profit organisation that has an objective of environmental conservation" (Fiedler \& Deegan, 2007, p. 413).

Confrontation, on the other hand, is anti-corporate campaigns (Arenas et al., 2009). NGOs, through confrontation, are not only pushing firms to meet agreed social expectations and formal legal requirements, but are also seeking to change broader expectations related to accountability, corporate social responsibilities, environmental stewardship, staff compensation, and government regulations (Burgos, 2013).

It can be seen from the above literature that the study on the NGOs and corporate environmental responsibility with respect to the developing countries is scant, not to mention on the study of the role of NGOs on corporate environmental responsibility in Ethiopia. From the literature reviewed so far, we have not found any study 
conducted in the context of Ethiopia. We are filling this gap by specifically examining pollution caused by industrial activities in Ethiopia and the role that can be played by the NGOs.

\section{Data collection and methodology}

Since one of the objectives of this study is to develop a practical framework for environmental NGOs to bring change on corporate environmental responsibility practices, qualitative method is more appropriate for this research. Another reason for selecting qualitative method is that this area of research is very limited. As a result, an in-depth investigation as to how the environmental NGOs bring a desired difference on corporate environmental responsibility practice and what strategies should they use to this end is important. We use both primary and secondary data. In collecting the primary data, we conducted extensive interviews, for an average time of about $45 \mathrm{~min}$, with four directors of environmental NGOs and one government official. The primary motivation for an in-depth structured interview is to have access to the relevant experiences and knowledge of NGOs' leaders as well as to have detailed information as much as possible.

In determining the sample size, a snowball sampling technique was used to identify possible respondents which are particularly useful in hard-to-track populations. Snowball sample, also called a referral sample, is one where the initial respondents typically are chosen using probability methods. Then the researcher uses the initial respondents to help identify the other respondents in the target population (Hair et al., 2007, p. 182). The reason for this is that there are more than five hundred NGOs registered and licensed by the Charity and Society Agency to work on environmental protection. However, as most of the registered NGOs are not active and did not have permanent addresses, random sampling becomes difficult to use. In collecting the secondary data, we use the memorandum and article of association, policy and strategy documents, publications, press releases, relevant proclamations and websites of the NGOs.

We employ content analysis to analyse the collected data. According to Krippendorff (2004, p. 18) content analysis is "a research technique for making replicable and valid inferences from texts (or other meaningful matter) to the context of their use". Content analysis is widely used in qualitative research technique (Hsieh \& Shannon, 2005). It is useful for this research objective because it allows to test theoretical issues to enhance understanding of the data (Elo \& Kyngäs, 2008). The analysis process includes open coding, creating categories and abstraction. For the purpose of data analysis, the interview transcripts are read again and again. At the first stage, transcripts are read in conjunction with listening to the audio recordings. This helped to get a general overview and to see a glimpse of how the data looks like. In the second stage, transcripts are re-read with an eye on identifying emerging patterns/issues which are classified using open codes. The open codes are then grouped to identify themes. Finally, the findings are presented by key themes together with illustrative quotes from the transcripts to substantiate different points. Context analysis of Ethiopia has also been used in this research as a complement method to content analysis. It is used to supplement data gained through interviews and to examine the validity of the data obtained through interview.

\section{Empirical findings}

As has been indicated in the abstract and Introduction section, this research aims at examining the role of environmental NGOs on corporate environmental responsibility. In doing so, we have investigated the existing environmental challenges in Ethiopia, the evolution of NGOs in Ethiopia and the perception of environmental NGOs. Based on our examination, we have developed a new framework for the environmental NGOs in Ethiopia. The detailed discussion of this has been presented below.

\section{Environmental challenges in Ethiopia}

Ethiopia is one of the beautiful countries located in North East Africa and it is endowed with rich wild life and eco-system. However, its natural beauty has largely been degraded as a result of human activities in general and industrial pollution in particular. The challenges are manifested in the form of deforestation, land degradation, climate change, water pollution, waste management, air pollution and noise pollution. According to the 2014 Environmental performance index published by Yale University, Ethiopia ranked 131st of 178 countries (Yale University, 2014). The major environmental issue posing a significant threat to Ethiopian environment is pollution caused by industrial discharges from manufacturing establishments in industrialized areas of the country (Ethiopia Cleaner Production Cetnre 2009). A recent study by the Ministry of Environment and Forestry reveals that out of the 163 factories surveyed, 101 (61.93\%) release their industrial wastes directly to the environment without any treatments (Ministry of Environment and Forestry, 2014). This indicates that economic 'development' is affecting the natural environment.

One of the reasons for environmental degradation in Ethiopia is that the companies in Ethiopia do not think in terms of environmental responsibility, but instead, for the most part, they are concerned with economic survival, as Robertson (2009) pointed out. On the other hand, the Ethiopian government has been criticized for 
remaining silent and not condemning corporate practices that are detrimental to the environment. This might not be a surprise since EPRDF (Ethiopian People Revolutionary Democratic Front), the ruling party which has been on power for the last 24 years, owned large business groups. The business groups controlled by the EPRDF is said to be one of the largest conglomerates in Sub-Saharan Africa (Altenburg, 2010) and engaged in a large number of industries including tannery, textiles, garments, pharmaceuticals, industrial engineering, construction and mining. In addition, EPRDF and the business elites including Sheik Mohammed Al Amoudi, who owns many of the leading factories across all economic sectors (Altenburg, 2010 and Kelsall, 2013), are closely entwined via dense shareholding and political relationships that are not transparent for the public (Altenburg, 2010).

It can be noted from the above discussion that the industries owned by the ruling party are highly pollutant and the government has lost its degree of independence to use the regulatory power on environmental protection. Moreover, since the pollutant industries are mostly owned by the ruling party, the government has less incentive to enforce any measure of corporate environmental responsibility practice. This poses a concern as to how the environmental challenges that the country is facing can be tackled. The answer to the concern can partly be found by reviewing the role of NGOs as representatives of civil society. NGOs have the capacity to fill the gap that neither the regulators nor the market provides by their representation.

\section{The evolution of NGOs in Ethiopia}

In Ethiopia, prior to the existence of "NGOs", some segments of Civil Society Organisations (CSOs) were operating. The first organizations in Ethiopia which can be defined as NGOs were traditional self-help systems. These self-help institutions, such as "Iddirs" and "Mahbers", have been there for time immemorial, adding diversity to the civil society landscape in Ethiopia (Christian Relief and Development Association 2006). In 1960 both foreign and local NGOs were established when these self-help groups could no longer suffice to support the needy of the country. The first NGOs in the form known today, that were established in the country, were the Ethiopian Red Cross and Swedish Save the Children. Following this and the famine of 1973 and later of 1984, the number of NGOs increased and these were mostly international. Later on with the change in government in 1990 a more conducive environment was established further encouraging the growth of NGOs in Ethiopia.

For more than half a century from the 1950s to 2009 some 3822 NGOs were registered to operate in Ethiopia in various areas. The new Charities and Societies Agency, since its establishment in 2009, has re-registered 739 national and international NGOs (Charities and Societies Agency, 2014). This means that nearly 40\% of the 3822 NGOs registered before the issuance of the new Proclamation. Currently more than 2000 NGOs have been reregistered under Proclamation No. 621/2009. Of these, more than 1600 are domestic and foreign charities working on development and welfare. As of 09 December 2014, there are more than five hundred NGOs registered and licensed by the agency to work on environmental protection.

In addition, the Agency has also registered close to 98 Ethiopian charities and societies which are allowed to work on human rights and conflict resolution.

According to Christian Relief and Development Association (2006), the development of NGOs in Ethiopia can be grouped into three phases. The first phase was the full engagement of the sector in relief and humanitarian work. The next phase was the period of gradual de-linking of relief and humanitarian work and focusing on basic service provision. In the third phase, in addition to the service delivery, NGOs/CSOs began to advance a rightsbased approach, governance and advocacy agendas.

\section{The Perception of NGOs on the environmental challenges}

We have specifically examined the perception of NGOs with respect to industrial pollution and we have found out that all the respondents of NGOs are highly concerned with the seriousness of the industrial pollution. The representative from one of the respondent NGOs explains the seriousness of industrial pollution by referring to the proportion of the industries that have primary waste treatment plant.

"More than $60 \%$ of the industries operating on the Ethiopian soil do not have waste treatment plant. They don't even have primary treatment plant. Most of the remaining $40 \%$ do not have the standard waste treatment mechanisms. So I am afraid to say the industries' production processes are environmental friendly and their products are clean," the respondent said.

We have also investigated as to what the perception of the NGOs on how the environmental protection should go along with the economic development. The results reveal that economic development should come first instead of environmental protection, according to some of the respondents. One of the representatives of the NGOs, for example, explained that it might take a while for the country to drag itself out of poverty if priority is given to environmental protection. The representative has underlined the high cost related to building a waste treatment plant in an industrial setting. According to the representative, forcing companies to put waste treatment 
mechanisms in place would discourage them and that eventually impair the economic development of the country.Another representative endorses economic development alongside with environmental protection and the representative has condemned any development that would come in the expense of the natural environment. The representative has put developing the economy and improving the livelihood of the people as the responsibility and the interest of the government. However, the representative regards protecting the natural environment as the interest of the environmental NGOs and said that harmonizing these two interests is the way forward.

The other respondent advocates economic growth that does not adversely affect not only the natural environment but also the society. The respondent mentioned,

"Yes, industries should be there. That is obvious. We would not develop in the absence of industries. We have to make use of the resources we have and get developed and feed our population. However, we should use the resources in a sustainable manner. Our developmental effort should not affect the environment; it should not affect the community negatively".

\section{The role of NGOs on corporate environmental responsibility practice}

Article 14 of Proclamation No.621/2009 permits NGOs to take part in environmental protection activities. The proclamation prohibits foreign NGOs and Ethiopian residence NGOs to take part in environmental right. Even if it hinders them, it documents a number of complementary activities that could be undertaken by all legal forms of NGOs in Ethiopian. Table 1 presents these areas. Some of those NGOs, which have legal right to take part in environmental protection activities, play significant role in the provision of training to the industries and brining the awareness of environmental damage and its protection. One of the NGOs has developed standards for environmental protection that should be used by the Ethiopian Environmental Protection authority.

The provision of information by conducting research on different environmental issues and publication are other roles that the NGOs play. They obtain, generate and disseminate environmental information through different channels. They also use the national and regional radio and television agencies to broadcast program that aimed at creating environmental awareness.

One of the respondents has an annual award program named by green award. This program recognises, acknowledge and celebrate good initiatives and outstanding achievements of individuals as well as for profit firms in protecting and enhancing the environment. On the top of that, it instigates others to contribute their share for the betterment of the environment, foster political will of the government and donors to invest in the environment.

The NGOs, as a representative of civil societies, have been participating in the process of drafting environmental related proclamation. They have also been organizing conferences, policy level debates and discussions as well as workshops related to environmental protection. They have also been involved in commenting on 'environmental impact assessment' report of companies. They also mobilize the public through establishing and strengthening local groups.

Table 1 Complementary activities that could be undertaken by Ethiopian, resident and foreign charities

\begin{tabular}{|c|c|}
\hline Ethiopian charities/societies ${ }^{a}$ & $\begin{array}{l}\text { Ethiopian resident } \\
\text { Charities/Societies } / \text { /Foreign Charities }^{c}\end{array}$ \\
\hline $\begin{array}{l}\text { Raise awareness on environmental rights. } \\
\text { Conduct research on the protection of environmental rights. } \\
\text { Law and policy reform. } \\
\text { Provide legal aid to victims of environmental pollution. } \\
\text { Work to bring violators of environmental rights to justice. }\end{array}$ & $\begin{array}{l}\text { Implement environmental protection programs, such as afforestation, } \\
\text { terracing, water and soil conservation, etc. } \\
\text { Undertake studies and organize forums on environmental issues such as climate } \\
\text { change, conservation of natural resources, environmental impact of industrial } \\
\text { and agricultural activities, etc. } \\
\text { Assess environmental protection activities by governmental and } \\
\text { non-governmental actors. } \\
\text { Educate the public on the utility of environmental protection and the adverse } \\
\text { impact of environmental degradation such as destruction of forests, erosion, } \\
\text { climate change, etc. } \\
\text { Encourage public initiatives to protect the environment through afforestation, } \\
\text { terracing, water and soil conservation, protection of wildlife, etc. } \\
\text { Conduct studies on industrial and other pollution and forward recommendations. } \\
\text { Support synergy between food security and agricultural development endeavours } \\
\text { with environmental protection and conservation of natural resources. }\end{array}$ \\
\hline
\end{tabular}

ander Article 2 of Proclamation No. 621/2009: Charities and societies proclamation 2009 "Ethiopian Charities" or "Ethiopian Societies" shall mean those Charities or Societies that are formed under the laws of Ethiopia, all of whose members are Ethiopians, generate income from Ethiopia and wholly controlled by Ethiopians. However, they may be deemed as Ethiopian Charities or Ethiopian Societies if they use not more than 10\% of their funds which is received from foreign sources bUnder Article 2 of Proclamation No. 621/2009: Charities and societies proclamation 2009 "Ethiopian Residents Charities" or "Ethiopian Residents Societies" shall mean those Charities or Societies that are formed under the laws of Ethiopia and which consist of members who reside in Ethiopia and who receive more than $10 \%$ of their funds from foreign sources

"Under Article 2 of Proclamation No. 621/2009: Charities and societies proclamation 2009 "Foreign Charities" shall mean those Charities that are formed under the laws of foreign countries or which consist of members who are foreign nationals or are controlled by foreign nationals or receive funds from foreign sources 
Framework for NGOs to influence corporate environmental responsibility practice in Ethiopia

There are a wide array of strategies and tactics available to NGOs to influence companies practice. However, all the strategies and tactics can be categorized either as 'confrontational' or 'collaborative' or 'direct' or 'indirect'. In the environmental literature, 'strategies' are sometimes separated from 'tactics'. 'Strategies' refers to whether or not to cooperate with government, media, primary stakeholders or other vocal groups to exert pressure to make firms incorporate social and environmental responsibility in their decision making process. What the NGOs would like to achieve is the most important factor that determine the strategies and tactics chosen by the NGOs.

From the existing studies the following figure can summarize the strategies and tactics available for NGOs to exert pressure on companies to influence their environmental performance.

The solid line indicates direct strategy. In this case, NGOs can directly confront a company or they can collaborate with the companies to help them improve their environmental performance. The broken line indicates the indirect strategies which show NGOs use of different entities such as media, government and primary stakeholders to influence the environmental performance of companies. In general terms, confrontation strategies such as boycott, demonstration, petition, monitor and expose actions (inaction) of others leads to moral stigmatization or "naming and shaming" of poor environmental performers. The above framework mainly shows how NGOs can reach corporations and impact their environmental performance practices.

The theoretical framework represented above will be impractical given the political, legal and economic situation of Ethiopia. This is because market based confrontation tactics like boycott companies' product and protesting against a firm, as the respondents indicated, are most likely to cause conflict not only with the targeted company but also with the government. Market based confrontation would be problematic in Ethiopia because as indicated the ruling party owned large industries like tannery, textiles, chemical, pharmaceuticals and mining which are commonly referred as highly pollutant industries. In addition, the business elites are closely entwined with top government officials via dense shareholding and political relationship. Therefore, confrontation would eventually jeopardize the continuity of the NGO as an entity.

Therefore, based on the above argument, this study develops the following framework which is most relevant to the existing situation of Ethiopia.

Relative to the framework indicated in Fig. 1, new entities are included in the new framework to mark the difference. These entities are general public, schools and universities. Arrow 1 on Fig. 2 represents direct strategy, NGOs-Companies collaboration. Collaboration in this case might take the form of awarding and publicizing companies having "better" environmental performance. This might also involve providing expertise or technical assistance to help companies to comply with the country's environmental legislation and regulations and meet international standards.

Moreover, NGOs should insist and collaborate with the government to enforce the existing environmental legislations and regulations. As most scholars agree, the Growth and Transformation Plan (GTP), Climate Resilience Green Economy Growth (CRGE) and other environmental legislations, regulations and standards have fairly embraced the principles of sustainable development. However, there is a wide gap between the policies' and strategies' intentions and the actual practices on the ground. Hence, the environmental NGOs should not advocate for policy change in Ethiopia but instead could voice for and do something about for the proper implementation of the existing policies and strategies to enforce the environmental legislation and regulation. Arrow 2A on Fig. 2 represents this strategy.

Most importantly NGOs should push the government to introduce the concepts of sustainable development and corporate environmental responsibility at all levels of the country's formal education system. This will help the country to have important and powerful agents that will champion best corporate environmental responsibility practice in the future. Arrow $2 \mathrm{~B}$ on Fig. 2 denotes this tactic.

The important and powerful agents include future politicians, business owners/managers, employees and most importantly consumers. These agents (specifically those to be business owners/managers, employees, consumers etc.) will improve corporate environmental responsibility practice from inside. To be politicians will also take political measures that will ultimately improve the environmental performance of the industries. The creation of awareness should be on the top of the environmental NGOs' and the government agenda. Therefore, NGOs should also insist the government to reach the general public through state owned media, public meetings and all other possible means in order to raise their environmental awareness. NGOs should also reach the general public by their own means and raise the public's environmental awareness. Environmentally conscious public will eventually force companies to improve their environmental performance through different mechanisms. Arrow 2c on Fig. 2 represents this tactic. The first two tactics (arrows 1 and 2A) will have immediate impact on corporate environmental responsibility. The impact of the other two tactics (arrows $2 \mathrm{~B}$ and 2C) on corporate environmental responsibility is ongoing. The goals of 


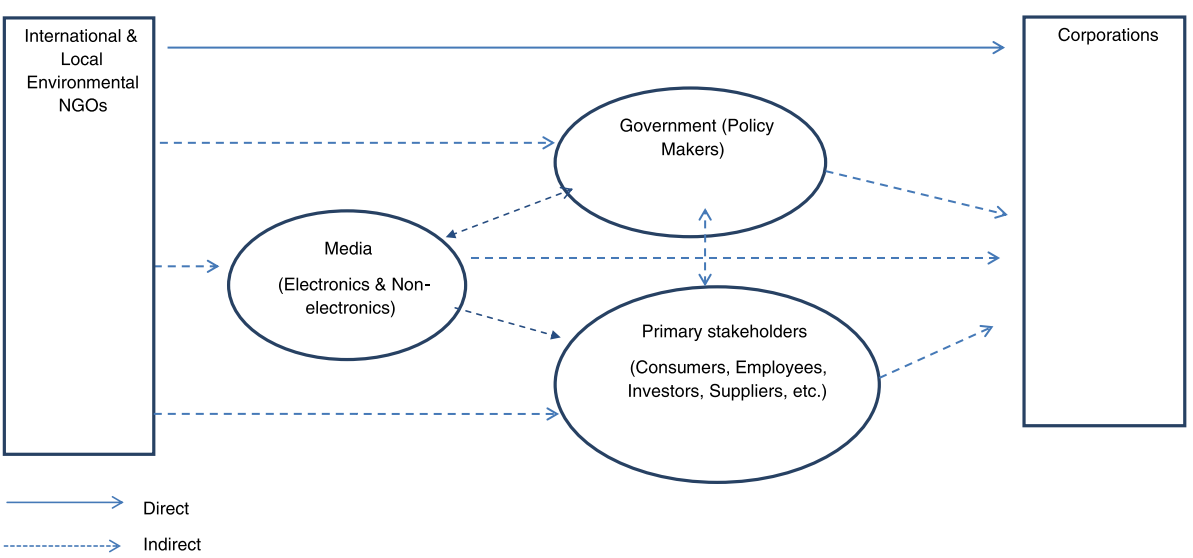

Fig. 1 Environmental NGOs' direct and indirect strategies

these tactics gear towards generating important and powerful actors that could ultimately improve corporate environmental responsibility practice in the future.

\section{Conclusion}

Ethiopia, as the case in most developing countries, encounters with the need to meet development objectives on one hand and environmental protection and conservation on the other hand. It is obvious in the country that 'business as usual' practices together with the projected industrial growth, the observed environmental pollution coupled with degradation caused by industries require improved corporate environmental responsibility practice.

Most prior studies in the area of corporate environmental responsibilities have been conducted within the context of the developed economies where environmental awareness and governmental regulations are prevalent. The study on the issue of corporate environmental responsibilities with the context of developing countries is very limited. The literature on corporate environmental responsibility in Africa is heavily dominated by the studies that focus on South Africa with bare consideration on Ethiopia. It should be noted that most studies in the case of Africa are based on colonized countries. However, colonization tends to influence the corporate environmental responsibility. It is vital to examine corporate environmental responsibility under the absence of colonial influence. Therefore, this study contributes to the existing literature by providing findings from a developing country perspective which has never been colonized.

This study provides an original framework that environmental NGOs can make use of in influencing companies to improve their environmental performance. The framework will help the NGOs to think more clearly about the effective strategies that they could adopt. Furthermore, this research enhances the understanding of the potential influences that environmental NGOs have on companies by outlining the roles that the NGOs are playing. This will enable other researchers in a different

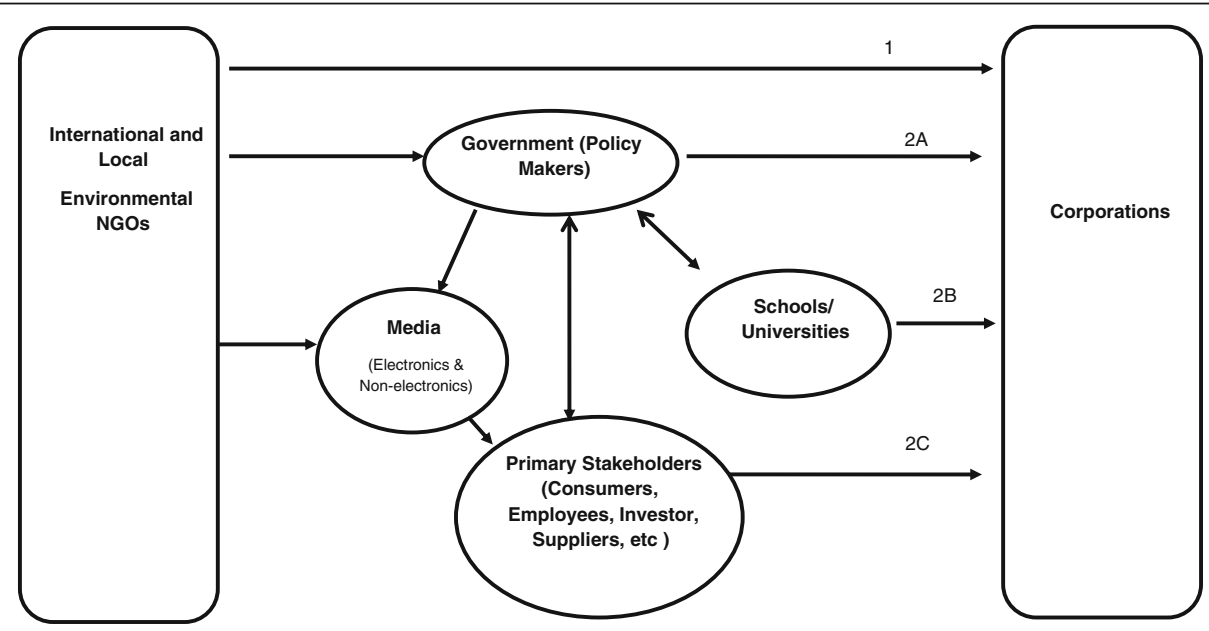

Fig. 2 Framework for NGOs to influence corporate environmental responsibility practice in Ethiopia 
setting to examine and explain the role NGOs can play in corporate environmental responsibility matters. This study will also have practical importance. As stated on the Climate-Resilience Green Economy Strategy (CRGE) document "Ethiopia wants to avoid the traps of businessas-usual development" (FDRE, 2011b, p. 7). To this end, the GTP and CRGE explicitly calls for stakeholders' involvement (FDRE, 2011a; MoFED, 2010). Therefore, the outcome of this research could enhance the participation of environmental NGOs in the green economy development endeavour of the country.

\section{Authors' contributions}

TA formulated the problem, collected data and did data analysis. VB provided direction and guidance. LGM provided feedback on an early draft of the paper and assisted with data analysis. All authors read and approved the final manuscript.

\section{Competing interests}

The authors declare that they have no competing interests.

\section{Publisher's Note}

Springer Nature remains neutral with regard to jurisdictional claims in published maps and institutional affiliations.

Received: 26 October 2016 Accepted: 5 March 2017

Published online: 17 March 2017

\section{References}

Ackers, B. (2009). Corporate social responsibility assurance: how do South African publicly listed companies compare? Meditari Accountancy Research, 17(2), 1-17.

Ählström, J., \& Sjöström, E. (2005). CSOs and business partnerships: strategies for interaction. Business Strategy and the Environment, 14(4), 230-240.

Altenburg, T. (2010). Industrial policy in Ethiopia. Retrieved from Bonn: http://edoc vifapol.de/opus/volltexte/2011/3323/pdf/DP_2.2010.pdf. Accessed 10 Apr 2015.

Arenas, D., Lozano, J. M., \& Albareda, L. (2009). The role of NGOs in CSR: mutual perceptions among stakeholders. Journal of Business Ethics, 88(1), 175-197.

Bakker, F. (2012). Exploring networks of activism on corporate social responsibility: suggestions for a research agenda. Creativity and innovation management, 21(2), 212-223.

Belal, A. R., \& Owen, D. (2007). The views of corporate managers on the current state of, and future prospects for, social reporting in Bangladesh: an engagement-based study. Accounting, Auditing \& Accountability Journal, 20(3), 472-494.

Belal, A. R., \& Roberts, R. W. (2010). Stakeholders' perceptions of corporate social reporting in Bangladesh. Journal of Business Ethics, 97(2), 311-324.

Burgos, S. (2012). NGOs, IGOs, and International law: gaining credibility and legitimacy through lobbying and results. Georgetown Journal of International Affairs, 13(1), 79-87.

Burgos, S. (2013). Corporations and social responsibility: NGOs in the ascendancy. Journal of business strategy, 34(1), 21-29.

Charities and Societies Agency. (2014). Monitoring Report Addis Ababa, Ethiopia.

Christian Relief and Development Association. (2006). Assessment of the Operating Environment for CSO/NGOs in Ethiopia. Addis Ababa: CRDA.

Clarkson, M. (1995). A stakeholder framework for analyzing and evaluating corporate social performance. The Academy of Management Review, 20(1), 92-117.

Danastas, L., \& Gadenne, D. (2006). Australian social and environmental NGOs. Journal of Corporate Citizenship, 2006(23), 53-66.

De Villiers, C.., \& van Staden, C. J. (2006). Can less environmental disclosure have a legitimising effect? Evidence from Africa. Accounting, Organizations and Society, 31(8), 763-781.

Deegan, C., \& Blomquist, C. (2006). Stakeholder influence on corporate reporting: an exploration of the interaction between WWF-Australia and the Australian minerals industry. Accounting, Organizations and Society, 31(4), 343-372.

Donaldson, T., \& Preston, L. E. (1995). The stakeholder theory of the corporation: concepts, evidence, and implications. The Academy of Management Review, 20(1), 65-91.
Elijido-Ten, E., Kloot, L., \& Clarkson, P. (2010). Extending the application of stakeholder influence strategies to environmental disclosures: an exploratory study from a developing country. Accounting, Auditing \& Accountability Journal, 23(8), 1032-1059.

Elo, S., \& Kyngäs, H. (2008). The qualitative content analysis process. Journal of advanced nursing, 62(1), 107-115.

Ethiopia Cleaner Production Cetnre. (2009). ). Promoting Resource Efficiency for Small and Medium Enterprises in Ethiopia. Addis Ababa: Ethiopian Cleaner Production Center.

FDRE. (2011a). Ethiopia's climate-resilient green economy: green economy strategy. Addis Ababa: MoFED.

FDRE. (2011b). The path to sustainable development: Ethiopian's climate resilience green economy strategy, Addis Ababa.

Fiedler, T., \& Deegan, C. (2007). Motivations for environmental collaboration within the building and construction industry. Managerial Auditing Journal, 22(4), 410-441.

Gray, B. (1989). Collaborating: finding common ground for multiparty problems. San Francisco: Jossey-Bass.

Hair, J. F., Money, A., Samouel, P., \& Page, M. (2007). Research methods for business. Chichester; Hoboken: John Wiley \& Sons Ltd.

Hartman, C. L., Stafford, E. R., \& Hofman, P. S. (1999). Partnerships: a path to sustainability. Business Strategy and the Environment, 8(5), 255-266.

Hsieh, H.-F., \& Shannon, S. E. (2005). Three approaches to qualitative content analysis. Qualitative health research, 15(9), 1277-1288.

Islam, M., \& Deegan, C. (2008). Motivations for an organisation within a developing country to report social responsibility information: evidence from Bangladesh. Accounting, Auditing \& Accountability Journal, 21(6), 850-874.

Kabir, H., \& Akinnusi, D. (2012). Corporate social and environmental accounting information reporting practices in Swaziland. Social Responsibility Journal, 8(2), 156-173.

Kelsall, T. (2013). Business, politics, and the state in Africa. GB: Zed Books.

Krippendorff, K. (2004). Content analysis: an introduction to its methodology. Thousand Oaks: Sage.

Ministry of Environment and Forestry. (2014). Survey on Factories' Environmental Pollution (Tanslated). Addis Ababa: Ministry of Environment and Forestry and MoFED.

Mitchell, R., Agle, B., \& Wood, D. (1997). Toward a theory of stakeholder identification and salience: defining the principle of who and what really counts. The Academy of Management Review, 22(4), 853-886.

MoFED. (2010). Growth and Transformation Plan: 2010/11-2014/15. Addis Ababa

Momin, A. (2013). Social and environmental NGOs' perceptions of corporate social disclosures: the case of Bangladesh. Accounting Forum, 37(2), 150-161.

O'Dwyer, B., Unerman, J., \& Bradley, J. (2005). Perceptions on the emergence and future development of corporate social disclosure in Ireland: Engaging the voices of non-governmental organisations. Accounting, Auditing \& Accountability Journal, 18(1), 14-44.

Ofori, D., \& Hinson, R. (2007). Corporate social responsibility (CSR) perspectives of leading firms in Ghana. Corporate Governance, 7(2), 178-193.

Pratten, J. D., \& Mashat, A. A. (2009). Corporate social disclosure in Libya. Social Responsibility Journal, 5(3), 311-327.

Proclamation No. 621/2009: Charities and societies proclamation, (2009)

Robertson, D. C. (2009). Corporate social responsibility and different stages of economic development: Singapore, Turkey, and Ethiopia. Journal of Business Ethics, 88(S4), 617-633.

Rodgers, C. (2000). Making it legit: New ways of generating corporate legitimacy in a globalising world. In J. Bendell (Ed.), Terms for endearment: Business, NGOs and sustainable development. Sheffield: Greenleaf Publishing.

Sandhu, D., \& Arora, P. (2012). Role and impact of environmental NGO's on environmental sustainability in India. Gian Jyotie Journal, 1(3), 93-104.

Starik, M. (1995). Should trees have managerial standing? Toward stakeholder status for non-human nature. Journal of Business Ethics, 14(3), 207-217.

Tilling, M., \& Davidson, R. (2006). NGO activism via website. Paper presented at the The 5th Australasian Centre for Social and Environmental Accounting Research Conference, Wellington, New Zealand. https://digital.library.adelaide.edu.au/dspace/bitstream/2440/ 55401/1/hdl_55401.pdf

Tilt, C. (1994). The influence of external pressure groups on corporate social disclosure: some empirical evidence. Accounting, Auditing \& Accountability Journal, $7(4), 47-72$ 
Tilt, C. (2004). Influences on corporate social disclosure: A look at lobby groups ten years on. School of Commerce Research Paper Series. Retrieved from http://www.flinders.edu.au/sabs/businessfiles/research/papers/2004/04-1.pdf. University, Y. (2014). Environmental Performance Index. Retrieved from http://epi.yale.edu/sites/default/files/2014_epi_report.pdf.

Villiers, D. (2003). Why do South African companies not report more environmental information when managers are so positive about this kind of reporting? Meditari Accountancy Research, 11(1), 11-23.

Winston, M. (2002). NGO strategies for promoting corporate social responsibility. Ethics \& International Affairs, 16(1), 71-87.

Yaziji, M., \& Doh, J. P. (2009). NGOs and corporations: conflict and collaboration. Cambridge: Cambridge University Press.

\section{Submit your manuscript to a SpringerOpen ${ }^{\circ}$ journal and benefit from:}

- Convenient online submission

- Rigorous peer review

- Immediate publication on acceptance

- Open access: articles freely available online

- High visibility within the field

- Retaining the copyright to your article

Submit your next manuscript at $>$ springeropen.com 